\title{
CAMPUR KODE BAHASA INGGRIS \\ DALAM TUTURAN BERBAHASA INDONESIA PADA PROGRAM PW BANGET RADIO ELRIA BUANA JAMBI
}

\author{
Ade Rahima ${ }^{1}$, Repha Krisdianti ${ }^{2}$ \\ Program Studi Pendidikan Bahasa dan Sastra Indonesia, \\ Fakultas Keguruan dan Ilmu Pendidikan, Universitas Batanghari, \\ Jambi \\ Ade_Rahima@yahoo.com \\ Rephakrisdianti123@gmail.com
}

\begin{abstract}
This research is aimed at describing two things, 1) the forms of English codemixing in the Indonesian utterance on the program PW Banget by Radio announcer Elria Buana Jambi, 2) the factors of code-mixing of English into Indonesian language by Radio announcer Elria Buana Jambi. This research is qualitative descriptive with content analysis technique. The data of this research was acquired from the broadcast record of Radio Elria Buana Jambi and interview with announcer of Radio Elria Buana Jambi. The result of this research are. 1) the forms of code-mixing in the form of word, phrase, and clause are as follows: there are 38 quotations in the form of word pieces; there are 15 quotations in the form phrase pieces; there are 2 quotations in the form of clause pieces; and the most dominant of code-mixing code occured is word pieces. 2) The dominant factor which causes the code-mixing by announcer of Radio Elria Buana Jambi is the identification of role which covers social and registral which is derived from three causes: a) the choice of language is adjusted with the condition of broadcasting program; $b$ ) the lack of English language ability of the announcer; c) the use of uncommon English language by the youth (unconventional).
\end{abstract}

Keywords: Code-mixing, English, Announcer.

\footnotetext{
${ }^{1}$ Dosen Program Studi Pendidikan Bahasa dan Sastra Indonesia, Fakultas Keguruan dan Ilmu Pendidikan, Universitas Batanghari, Jambi

${ }^{2}$ Mahasiswa Program Studi Pendidikan Bahasa dan Sastra Indonesia, Fakultas Keguruan dan Ilmu Pendidikan, Universitas Batanghari, Jambi

Campur Kode Bahasa Inggris dalam Tuturan Berbahasa Indonesia pada Program Pw Banget Radio Elria Buana Jambi
} 


\section{PENDAHULUAN}

Bahasa dan kehidupan seperti dua sisi mata uang yang tidak dapat terpisahkan. Dalam kehidupan bermasyarakat, manusia membutuhkan bahasa untuk berkomunikasi. Bahasa digunakan masyarakat sebagai alat pergaulan antarsesama dan alat untuk menyampaikan buah pikiran (Rofii dan Hasibuan; 2019). Menurut Pernando dan Ade Rahima (2018:1) peristiwa komunikasi yang berlangsung dalam kehidupan manusia bertujuan sebagai sarana untuk mengungkapkan ide, gagasan, isi pikiran, perasaan, keinginan dan

sebagainya.

Pemakaian bahasa oleh masyarakat sangat beragam terutama di Indonesia. Menurut Rahima dan Tayana (2019:134) hal ini disebabkan karena negara Indonesia merupakan negara yang memiliki banyak bahasa bahasa daerah dan masing-masing bahasa mempunyai dialek sendiri. Keberagaman bahasa yang digunakan oleh masyarakat Indonesia itulah yang menyebabkan masyarakat Indonesia menjadi masyarakat yang multilingual. Nababan (1993:27) berpendapat bahwa masyarakat Indonesia cenderung menggunakan bahasa yang berlainan bahkan mereka menggunakan lebih dari satu bahasa, seperti masyarakat Melayu Jambi mereka menggunakan bahasa daerah, bahasa Indonesia dan bahasa asing. Persoalan multilingual tersebutlah yang akan menyebabkan peristiwa kebahasaan yaitu campur kode.

Campur kode dapat terjadi karena terbatasnya kompetensi dan performasi seorang ketika menggunakan dua bahasa. Secara sederhana dapat dikatakan bahwa terdapat ketidakseimbangan pemakaian antara satu bahasa dengan bahasa yang lain. Selain itu, dalam penerapannya campur kode bisa terjadi dalam situasi formal maupun situasi informal. Namun kenyataannya, peristiwa campur kode cenderung terjadi pada situasi yang tidak resmi karena pemakaian bahasa yang santai, akrab dan tidak baku (Rahima dan Tayana, 2019:135).

Campur kode dapat terjadi karena tidak ada keseimbangan pemakaian antara bahasa Indonesia (B1) dan bahasa Inggris (B2). Bahasa pertama (B1) dapat mempengaruhi penggunaan bahasa kedua (B2) (Rofii, 2015). Biasanya hal seperti ini sering terjadi pada saat seseorang dalam proses belajar bahasa kedua, akibatnya akan terjadi kekacauan atau interferensi dalam pemakaian bahasa (Nababan, 1993:35). Berdasarkan hasil observasi penulis pada saat mendengarkan siaran Radio Elria Buana Jambi, sering terjadi peristiwa campur kode yang dilakukan kalangan penyiar radio. Tidak banyak pengguna bahasa yang memperhatikan kaidah kebahasaan yang baik dan benar, sehingga banyak yang menjadikan campur kode sebagai hal yang biasa dan lumrah. Hal ini mengakibatkan terjadi kekacauan bahasa. Peristiwa kebahasaan inilah yang membuat penelitian tentang peristiwa campur kode di kalangan penyiar radio ini penting untuk dilakukan.

Penyiar radio menggunakan bahasa sebagai sarana berkomunikasi dengan pendengarnya. Penyampaian bahasa dilakukan secara lisan. Dalam penyiaran radio seorang penyiar yang menggunkan B1 akan secara spontan menggunakan B2 saat berbicara, hal ini disebabkan oleh ketidakseimbangan bahasa yang dikuasainya. Contoh dari pencampuran antara B1dan B2 seorang penyiar radio pada tanggal 11 Januari

\section{Campur Kode Bahasa Inggris dalam Tuturan Berbahasa Indonesia pada Program Pw Banget} Radio Elria Buana Jambi 
2019 dalam program $P W$ Banget Radio

Elria Buana adalah sebagai berikut:

"Buat kamu yang penasaran tentang track (lagu dalam album) terbaru yang akan aku putarin, makanya stay tune (tetap dengarkan) terus".

Penggunaan bahasa asing oleh penyiar radio menjadi hal yang biasa terutama bahasa Inggris, karena pengaruh dari perkembangan budaya. Berdasarkan hasil wawancara dengan salah satu penyiar radio EB, program-program yang ada di radio EB juga sangat dekat sekali dengan kehidupan remaja saat ini, salah satu dari programnya yaitu program $P W$ Banget atau"pas waktunya banget". Program ini membahas mengenai informasi terbaru tentang dunia musik dan juga membahas tentang hal-hal yang unik di seluruh dunia sebagai pengetahuan baru untuk pendengarnya (EB, 2018).

Beberapa alasan penelitian ini penting untuk dilakukan, sebagai berikut.

1. Campur kode terjadi karena masyarakat Indonesia yang multilingual termasuk masyarakat Melayu Jambi.

2. Campur kode akan mengakibatkan interferensi dalam pemakaian bahasa Indonesia.

3. Pemakaian campur kode oleh penyiar radio akan membuat banyak masyarakat melakukan pristiwa yang sama dan menjadikannya sebagai hal lumrah (biasa).

Berdasarkan uraian latar belakang tersebut, maka penelitian ini dilakukan.

Berdasarkan uraian latar belakang tersebut, digunakan pendapat Suwito (dalam Rokhman, 2013:38) bahwa terdapat dua penyebab terjadinya campur kode yaitu bersifat keluar dan ke dalam. Campur kode keluar yaitu: 1) identifikasi peranan, 2) identifikasi ragam, 3) keinginan untuk menafsirkan, sementara campur kode kedalam yaitu: 1) penutur, 2) lawan tutur, dan 3) bentuk bahasa.

Fokus penelitian ini yaitu mendeskripikan faktor penyebab terjadinya campur kode bahasa Inggris dalam tuturan berbahasa Indonesia pada program $P W$ Banget oleh penyiar radio Elria Buana Jambi tanggal 11 Maret-22 Maret 2019, dengan fokus kepada penyebab campur kode yang bersifat keluar.

Berdasarkan fokus penelitian tersebut maka, penelitian ini bersusaha untuk menjawab pertanyaan faktor apasajakah yang menyebabkan terjadinya campur kode bahasa Inggris dalam tuturan berbahasa Indonesia pada program $P W$ Banget dalam siaran Radio Elria Buana?

Adapun tujuan penelitian ini yaitu untuk mendeskripsikan faktor yang menyebabkan terjadinya campur kode bahasa Inggris dalam tuturan berbahasa Indonesia pada program $P W$ Banget dalam siaran Radio Elria Buana.

Adapun manfaat penelitian ini dijelaskan sebagai berikut.

1) Secara teoritis penelitian ini diharapkan dapat berdampak positif dengan memberikan pengetahuan yang jelas mengenai bentuk campur kode dan faktor penyebab terjadinya campur kode dalam siaran Radio Elria Buana, selain itu penelitian ini dapat digunakan sebagai pengembangan dari berbagai teori sosiolinguistik terutama mengenai campur kode.

2) Secara praktis penelitian ini diharapkan dapat memberikan mafaat sebagai berikut:

a. Bagi peneliti lain, dapat menjadi referensi dan acuan dalam menulis tentang campur kode bahasa asing.

b. Bagi penyiar, hasil penelitian ini dapat memperkaya ilmu pengetahuan 
dan menjadi pembelajaran yang baru.

c. Bagi mahasiswa, hasil penelitian ini dapat digunakan untuk menambah bahan bacaan.

\section{METODE PENELITIAN}

Jenis penelitian ini adalah deskriptif kualitatif. penelitian ini mendeskripsikan bagaimana faktor penyebab campur kode bahasa Inggris dalam tuturan berbahasa Indonesia pada program $P W$ Banget oleh penyiar radio Elria Buana Jambi. Danim (2002:41) mengatakan "Studi deskriptif adalah alat untuk menemukan makna baru, menjelaskan kondisi keadaan, menentukan frekuensi kemunculan sesuatu, dan mengkategorikan informasi". Selanjutnya, "Penelitian kualitatif merupakan suatu strategi inquiri yang menekankan pencarian makna, pengertian, konsep, karakteristik, gejala, simbol, maupun deskrisi tentang suatu fenomena" (Yusuf, 2014:329).

Data pada penelitian ini berupa tuturan campur kode bahasa Inggris dalam tuturan berbahasa Indonesia pada program $P W$ Banget oleh penyiar radio Elria Buana Jambi. "Sumber data utama dalam penelitian kualitatif ialah katakata, tindakan selebihnya adalah data tambahan seperti dokumen dan lain-lain" (Lofland dalam Moleong, 2001:112). Data dalam penelitian ini bersumber dari Radio Elria Buana Jambi pada program $P W$ Banget.

Penelitian ini menggunakan teknik wawancara sebagai cara untuk mendapatkan data awal penyebab terjadinya campur kode pada penyiar radio dan teknik rekam untuk mendapatkan data yang akurat, data yang dimaksud merupakan fenomena campur kode yang terdapat pada tuturan penyiar Radio Elria Buana Jambi.
Langkah-langkah pengumpulan data dalam penelitian ini sebagai berikut.

1. Wawancara, pada penelitian ini, penulis memakai teknik wawancara agar mendapatkan pemahaman mengenai penyebab terjadinya campur kode pada penyiar Radio Elria Buana Jambi.

2. Rekam, pada penelitian ini penulis menggunakan teknik rekam untuk mendapatkan data yang akurat dari tuturan penyiar radio Radio Elria Buana Jambi yang melakukan campur kode.

Teknik analisis data digunakan sebagai teknik lanjutan dari teknik pengumpulan data. Menurut Sugiyono (2007:335) "Analisis data adalah proses mencari dan menyusun secara sistematis data yang diperoleh dari hasil wawancara, catatan lapangan dan dokumentasi dengan cara mengorganisasikan data kedalam kategori, menjabarkan kedalam unit-unit, melakukan sintesa, menyusun kedalam pola, memilih mana yang penting dan akan dipelajari, dan membuat kesimpulan sehingga mudah dipahami oleh diri sendiri maupun orang lain".Darmono (2002:34) "Analisis data kualitatif bisa menggunakan teknik analisis studi kasus, analisis multisitus, etnografi, dan analisis isi”.

Teknik analisis data dalam penelitian ini menggunakan teknik analisis isi. Berikut beberapa langkah dalam menganalisis data berdasarkan analisis isi.

1. Membagi aspek yang dibahas berdasarkan kategorinya berdasarkan tabel.

2. Memberikan kode dan menjelaskan dalam bentuk kalimat.

3. Menganalisis dan mengklasifikasi bentuk campur kode dan faktor campur kode berdasarkan kategorinya. 
4. Memberikan gambaran dalam bentuk deskriptif kualitatif secara keseluruhan mengenai bentuk campur kode dan faktor campur kode berdasarkan kategorinya pada siaran radio Elria Buana.

\section{HASIL DAN PEMBAHASAN}

Berdasarkan analisis data yang telah dilakukan, Berikut ini adalah faktor penyebab terjadinya campur kode berdasarkan kategori a) identifikasi peranan, b) identifikasi ragam dan c) keinginan untuk menjelaskan.

\section{a. Faktor Identifikasi Peranan terhadap Campur Kode Bahasa Inggris dalam Tuturan Berbahasa Indonesia pada Program $P W$ Banget Radio Elria Buana Jambi}

Faktor penyebab terjadinya campur kode yang berupa identifikasi peranan terdapat sebanyak 3 datayang didapatkan dari hasil wawancara bersama seorang penyiar Radio Elria Buana Jambi pada program $P W$ Banget. Sesuai dengan teori untuk menganalisis faktor penyebab terjadinya campur kode berdasarkan identifikasi peranan yang dikemukakan oleh Suwito (dalam Rokhman, 2013:39). Berikut merupkan penjelasan lebih lanjut mengenai faktor penyebab terjadinya campur kode berdasarkan identifikasi peranan.

1. Mariah carey itu mengubah sebuah gerbong subway menjadi lokasi sebuah party. (b3)

2. Yes seperti biasa nih ya si mariah carey itu terlihat flawless secara fisik maupun lengkingan vokal nya. (b4)

3. Dari Vanesha Prissila featuring panas dalam band ya yang lagunya berpisah. (b9)
Ketiga kutipan campur kode dalam bentuk serpihan kata di atas, merupakan faktor campur kode yang termasuk dalam identifikasi peranan yang mencakup sosial dan registral. Hal ini diperoleh berdasarkan hasil wawancara dengan penyiar yaitu pemilihan bahasa yang menyesuaikan kondisi program siaran. Kutipan-kutipan bahasa Inggris tersebut ialah kata yang sering digunakan oleh kalangan anak muda dan lebih banyak di pahami.

1. Mariah carey itu mengubah sebuah gerbong subway menjadi lokasi sebuah party. (b2)

2. Next itu juga pas dia nelusurin ranjang gitukan ketemu sama j balvin dan juga tainyyang kemudian membawakan versi bahasa spanyol lagunya. (b13)

3. Lady Gaga masuk dan memenangkan piala-piala prestiges seperti grammy. (b15)

Ketiga kutipan campur kode tersebut merupakan faktor campur kode yang termasuk dalam identifikasi peranan yang mencakup sosial. Hal ini diperoleh berdasarkan hasil wawancara dengan penyiar yaitu kurangnya kemampuan penguasaan bahasa Inggris oleh penyiar. Pada pernyataan tersebut dapat diartikan bahwa pola pikir seorang penyiar radio tersebut telah terbentuk berdasarkan keadaan sosialnya dalam kehidupan sehari-hari sehingga akan terbawa pada saat siaran radio.

1. Sarah bakalan puterin lagu yang baru in banget. (b1)

2. Mariah carey itu mengubah sebuah gerbong subway menjadi lokasi sebuah party. (b2)

3. Yesseperti biasa nih ya si mariah carey itu terlihat flawless secara 
fisik maupun lengkingan vokal nya. (b5)

Ketiga kutipan campur kode tersebut merupakan faktor campur kode yang termasuk dalam identifikasi peranan yang mencakup sosial. Hal ini diperoleh berdasarkan hasil wawancara dengan penyiar yaitu penggunaan bahasa Inggris yang tidak biasa dikalangan remaja (tidak sesuai dengan kaidah) yang berarti ada rasa gengsi oleh penyiar tersebut sehingga melakukan peristiwa campur kode. Rasa gengsi tersebut termasuk pada bagian sosial dalam identifikasi peranan.

\section{b. Faktor Identifikasi Ragam terhadap Campur Kode Bahasa Inggris dalam Tuturan Berbahasa Indonesia pada Program $P W$ Banget Radio Elria Buana Jambi}

Faktor penyebab terjadinya campur kode yang berupa identifikasi ragam terdapat sebanyak 1 data yang diperoleh dari hasil wawancara bersama seorang penyiar Radio Elria Buana Jambi pada program $P W$ Banget. Sesuai dengan teori untuk menganalisis faktor penyebab terjadinya campur kode berdasarkan identifikasi ragam yang di kemukakan oleh Suwito (dalam Rokhman, 2013:39). Berikut ini merupakan penjelasan lebih lanjut mengenai faktor penyebab terjadinya campur kode berdasarkan identifikasi ragam.

1. Kalo misalkan beruntung ni yah klipnya bisa memberikan dorongan untuk performanya di lagu chart.

2. Buat kamu yang penasaran coming soon nih bakalan ada di playlist EB.

3. Penasaran kan pasti sarah bakal ngebahas apa nanti stay tune terus di 102,7 eb fm.

Campur Kode Bahasa Inggris dalam Tuturan Berbahasa Indonesia pada Program Pw Banget Radio Elria Buana Jambi
Ketiga kutipan campur kode di atas merupakan faktor campur kode yang termasuk dalam identifikasi ragam. Hal ini diperoleh berdasarkan hasil wawancara dengan penyiar yaitu pencampuran kode merupakan ciri khas penyiar menjelaskan bahwa seorang penyiar radio itu bisa dibilang mempunyai ciri khas menggunakan bahasa Indonesia dan bahasa Inggris pada saat siaran dan itu termasuk pada identifikasi ragam.

\section{c. Faktor Keinginan untuk Menjelaskan terhadap Campur Kode Bahasa Inggris dalam Tuturan Berbahasa Indonesia pada Program PW Banget Radio Elria Buana Jambi}

Faktor penyebab terjadinya campur kode yang berupa keinginan untuk menjelaskan terdapat sebanyak 1 data dari hasil wawancara bersama seorang penyiar Radio Elria Buana Jambi pada program $P W$ Banget. Sesuai dengan teori untuk menganalisis faktor penyebab terjadinya campur kode berdasarkan keinginan untuk menjelaskan atau menafsirkan yang di kemukakan oleh Suwito (dalam Rokhman, 2013:39). Berikut ini merupakan penjelasan lebih lanjut mengenai faktor penyebab terjadinya campur kode berdasarkan keinginan untuk menjelaskan.

1. Dari vanesha prissila featuring panas dalam band ya yang lagunya berpisah.

2. Dia nge upload video rumahnya yang kebanjiran terus banyak banget sekelompok ikan nyerbu ke dalam rumah.

3. Jadi setting nya itu kayak disebuah ranjang raksasa yang gede gitu.

Ketiga kutipan campur kode di atas merupakan faktor campur kode yang termasuk dalam keinginan untuk 
menjelaskan. Hal ini diperoleh berdasarkan hasil wawancara dengan penyiar yaitu tidak menemukan kata yang tepat dalam bahasa Indonesia. faktor penyebab campur kode berdasarkan kutipan tersebut yaitu karena adanya keinginan untuk menjelaskan sesuatu oleh penyiar radio tersebut.

\section{SIMPULAN}

Berdasarkan hasil penelitian dan pembahasan yang telah dijabarkan, maka dapat disimpulkan bahwa di dalam Campur Kode Bahasa Inggris dalam Tuturan Berbahasa Indonesia pada Program $P W$ Banget Radio Elria Buana Jambi Tanggal 11-22 Maret terdapat faktor penyebab terjadinya campur kode yang dominan yaitu berupa identifikasi peranan yang mencakup sosial dan registral berupa: 1) pemilihan bahasa yang menyesuaikan kondisi program siaran; 2) kurangnya kemampuan penguasaan bahasa Inggris oleh penyiar, 3) penggunaan bahasa Inggris yang tidak biasa dikalangan remaja (tidak sesuai dengan kaidah).

\section{Saran}

Terkait dengan penelitian ini terdapat beberapa saran yang dapat disampaikan.

1. Melihat dari banyaknya peristiwa campur kode berupa serpihan kata pada penelitian ini maka sebaiknya seorang penyiar radio dapat memanfaatkan penggunaan kata dalam bahasa Inggris sebaik mungkin dan menggunakannya sesuai dengan kebutuhan penyiaran.

2. Walaupun dalam penelitian ini seorang penyiar radio mengikuti ciri khas bahasa seorang penyiar tetapi tetap harus berpedoman pada ketentuan bahasa. Selanjutnya, seorang penyiar radio sebaiknya memiliki kemampuan berbahasa yang

Campur Kode Bahasa Inggris dalam Tuturan Berbahasa Indonesia pada Program Pw Banget Radio Elria Buana Jambi 


\section{April 2019}

aksara.unbari.ac.id/index.php/aksara/ article/download/94/50.

Rokhman, Fathur. (2013). Sosiolinguistik

(Suatu Pendekatan Pembelajaran

Bahasa dalam Masyarakat

Multikultural). Yogyakarta: Graha

Ilmu.

Sugiyono. (2007). Metode Penelitian

Pendidikan (Pendekatan

Kualitatif, Kuantitatif, dan $R \& D$.

Bandung: Alfabeta.

Yusuf, Muri. (2014). Metode Penelitian:

Kuantitatif, Kualitatif, dan

penelitian Gabungan. Jakarta:

Prenadamedia Group. 